\title{
磁界共振結合を利用したボディエリア通信の提案と検討
}

\section{Proposal and Investigation of Body Area Communication Using Magnetic Resonance Coupling}

越地 福朗 ${ }^{* 1},{ }^{* 3}$ (正員)， 湯山 菜奈子 ${ }^{* 1}$, 越地 耕二 ${ }^{* 2, * 3}$ (正員)

\author{
Fukuro KOSHIJII (Mem.), Nanako YUYAMA, Kohji KOSHIJI (Mem.)
}

\begin{abstract}
In this paper, a new highly efficient wireless communication link around human body using magnetic resonance coupling was proposed and investigated. The communication between wearable devices located on forearm and upper arm, like a wristwatch or armband, is assumed as a model for body area communication. The transmission characteristics $S_{21}$, between transmitting and receiving antenna which is put on forearm and upper arm, respectively, like a wristwatch or armband, were analyzed and measured. As a result, the transmission characteristics $S_{21}$ showed the maximum value of $-3 \mathrm{~dB}$, and was excellent compared with that of conventional body area communication using the electrodes in contact with the body. Moreover, the SAR of the body was less than a three-hundredth compared with the safety limit of $2 \mathrm{~W} / \mathrm{kg}$. Therefore, we confirmed that the wireless communication link using magnetic resonance coupling is useful for body area communication.
\end{abstract}

Keywords: magnetic resonance coupling, body area network, wearable device, electromagnetic field analysis, FDTD method, specific absorption rate, measurement.

\section{1 はじめに}

近年，高密度実装技術や微細加工技術の進化にとも ない，電子機器は小型・軽量化が進み，モバイルから ウェアラブルへと進化しつつある。特に，医療・ヘル スケア分野においては，これらのウェアラブル機器を 人体周囲に分散配置し，ボディエリアネットワークと 呼ばれる通信ネットワークを形成して，ワイヤレスで 生体情報を収集，解析，管理する健康管理サービスな ども提案されている[1,2]。

ボディエリアネットワークの有力な通信方式のひ とつに人体通信[3]が挙げられるが，損失性媒質である 人体が信号の伝送媒体となるため, たとえば, 装着さ れる腕時計型ウェアラブル機器と手のひらに配置され るデータ端末との間の通信特性 $S_{21}$ は, およそ-50dB に とどまる[4]。

本稿では，より良好な伝送特性を実現する新しいボ ディエリアネットワーク技術として, 磁界共振結合を 利用したボディエリアネットワークを提案し, 人体腕 部にアンテナを装着したときのアンテナ間の伝送特性 を検討する。

連絡先： 越地 福朗, $\bar{\top} 154-8515$ 東京都世田谷区世田谷 4-28-1, 国士舘大学理工学部理工学科電子情報学系 e-mail: koshiji@kokushikan.ac.jp

${ }^{* 1}$ 国士舘大学理工学部理工学科電子情報学系

*2 東京理科大学理工学部電気電子情報工学科

*3 東京理科大学総合研究機構

\section{2 提案するボディエリア通信システムの構成}

Fig. 1 に，本稿で想定するボディエリアネットワー クの構成を示す。Fig. 1(a)に示すように上腕部および前 腕部に装着したウェアラブル機器同士の通信を想定す る。また，同図(b)に示すように通信用のアンテナコイ ルはウェアラブル機器を腕部に固定するバンド部分に リング状に内蔵する構成とする。

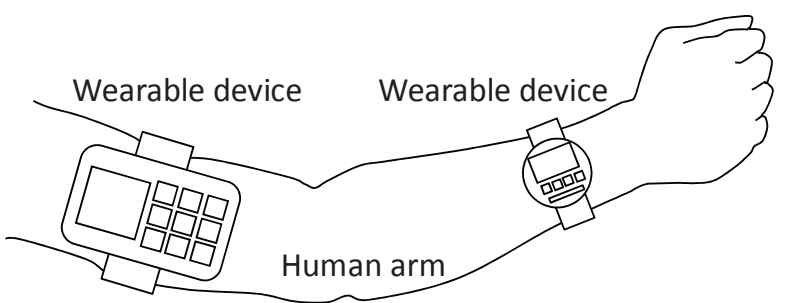

(a) Body area network between wearable devices put on upper and fore arms

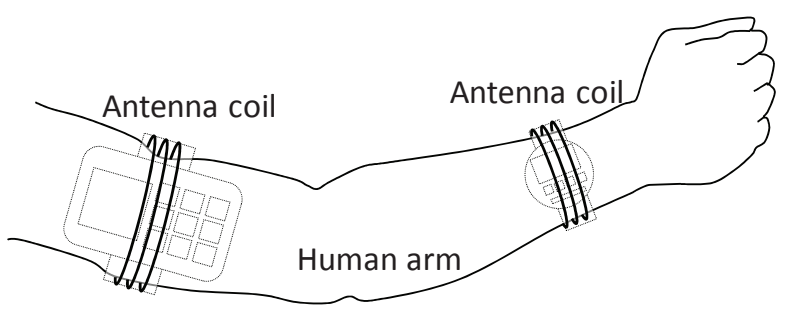

(b) Antenna coil alignment in wearable devices

Fig. 1 Body area network using magnetic resonance coupling. 


\section{3 電磁界解析モデルおよび測定用ファントム}

Fig. 2 は，Fig. 1 に示したシステムを電磁界解析用に 単純化したモデルである。著者らは，過去の検討にお いて，腕部の折り曲げによるアンテナコイルの配置・ 傾き変動に対する伝送特性変動が-3 dB 程度と小さい ことを確認している[5]。そのため，本稿では，Fig. 2 に示すように，腕を伸ばした状態を想定する円柱状の モデルを用いた検討を行う。同困に示すように，腕部 は, 筋肉の電気特性 (導電率 $\sigma=0.69 \mathrm{~S} / \mathrm{m}$, 比誘電率 $\varepsilon_{r}$ $=72 @ 64 \mathrm{MHz}$ ) を有する媒質とし $[6,7]$, 日本人の平 均体型を考慮し, 腕部長 $L_{a r m}=650 \mathrm{~mm}$, 腕部半径 $R_{a r m}$ = $40 \mathrm{~mm}$ の円柱でモデル化している[8]。また, ウェア ラブル機器装着部分には, 半径 $r=50 \mathrm{~mm}$, ピッチ $p=$ $10 \mathrm{~mm}$, 巻数 $n=5$ 回のアンテナコイルを配置する。送 信アンテナコイルの励振源には, 内部抵抗 $50 \Omega$ の信号 源を用い, 受信アンテナコイルの受信抵抗は $50 \Omega$ とす る。電磁界解析には, Finite Difference Time Domain (FDTD)法を用いる。

測定においては，携帯電話や Radio Frequency Identification(RFID)などの電子機器の発する電磁波の 体内埋め込み型医用機器へ及ぼす影響調査などに利用 されている濃度 $0.18 \%$ の食塩水をポリ塩化ビニルの円 筒容器に入れて構成したファントムを用いる $[9,10]$ 。 Fig. 3 は，測定に用いたファントムの写真である。円 筒容器の内側半径は解析モデルと同様の $R_{\text {arm }}=40 \mathrm{~mm}$ としている。そして, 円筒容器の外壁に発泡スチロー ルをスペーサとして挿入し, 円筒容器の中心から半径 $r=50 \mathrm{~mm}$ の位置に, ピッチ $p=10 \mathrm{~mm}$, 巻数 $n=5$ 回 のアンテナコイルを配置する。測定はネットワークア ナライザによって行う。

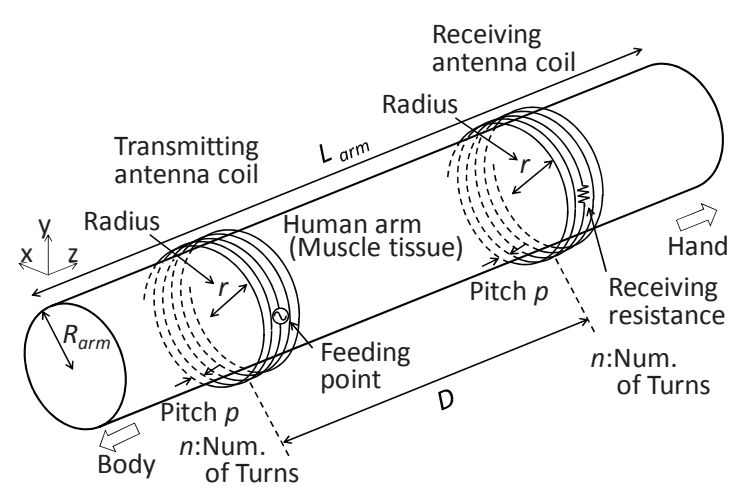

Fig. 2 Model for electromagnetic field analyses.

\section{4 アンテナコイルの入カインピーダンス特性}

Fig. 4 は，Fig. 2 において，送受信アンテナコイル間 隔 $D=300 \mathrm{~mm}$ としたときの人体に装着された送信ア ンテナコイルの入力インピーダンス特性を電磁界解析 した結果である。Fig. 4 からわかるとおり，送信アン テナコイルの入カインピーダンス特性は, $64 \mathrm{MHz}$ に おいて直列共振状態, $114 \mathrm{MHz}$ において並列共振状態 となることがわかる。

\section{5 送受信アンテナコイル間の伝送特性}

\section{1 送受信アンテナコイル間距離に対する伝送特性}

Fig. 1(a)に示すような腕部にウェアラブル機器を装 着することを想定すると, 腕部の装着位置，すなわち 送受信アンテナコイル間の距離によって伝送特性が変 動することが予想される。ここでは，伝送距離に対す る伝送特性の変動がどの程度あるか検討を行う。

Fig. 5 は，Fig. 2 において，送受信アンテナコイル間 隔 $D$ を 100〜350 mm としたときの送受信アンテナコ

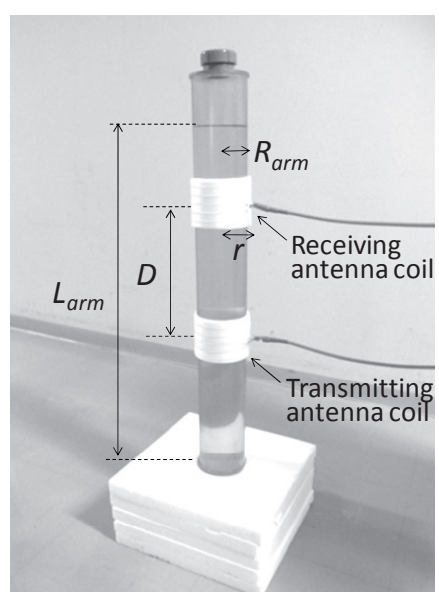

Fig. 3 Phantom arm model for measurements.

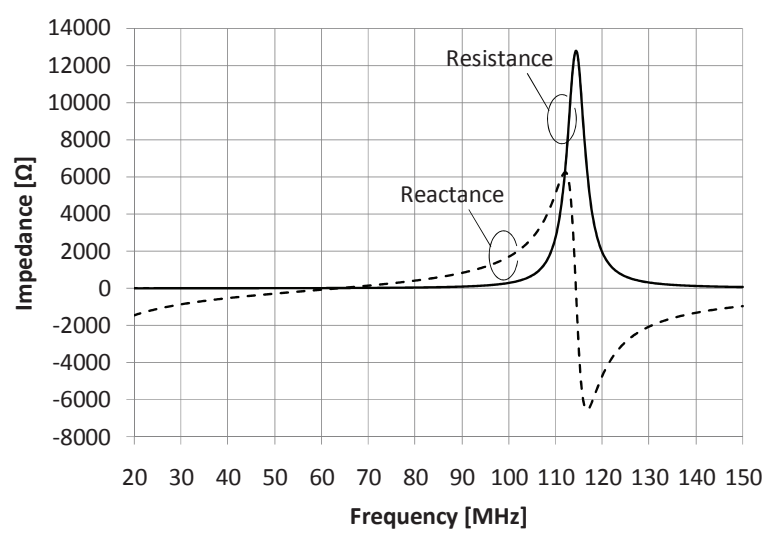

Fig. 4 Input impedance characteristics of antenna coil. 
イルの反射特性 $S_{I I}$ および送受信アンテナコイル間の 伝送特性 $S_{21}$ を電磁界解析した結果である。また, Fig. 6 は, Fig. 3 に示寸ファントムを用いて, 電磁界解析同 様に, 送受信アンテナコイルの反射特性 $S_{I l}$ および送受 信アンテナコイル間の伝送特性 $S_{21}$ を測定した結果で ある。

Figs. 5, 6 に示寸解析值と測定值をみると, それぞれ のアンテナコイルが直列共振する $63 \mathrm{MHz}$ および 64 $\mathrm{MHz}$ において, 反射特性 $S_{I I}$ は最小值を, 伝送特性 $S_{21}$ は最大值をとり, 解析值および測定值はほぼ一致して いることがわかる。このことから，電磁界解析モデル が妥当であることが確認できる。ここで，伝送特性 $S_{21}$ を見ると，低域側および高域側で解析值と実験值に若 干の差異が生じているが，これは，測定においては測 定用のケーブルやコネクタを使用しており，この点が 電磁界解析のモデルとは異なるためであると考えられ る。

さらに, Fig. 5 および Fig. 6 から，手首と手のひら間 の距離を想定する伝送距離 $D=100 \mathrm{~mm}$ では, 解析值 および測定値ともに $S_{21}=-3 \mathrm{~dB}$ 程度, 手首と上腕間の 距離を想定する $D=350 \mathrm{~mm}$ では, 解析值および測定 值ともに $S_{21}=-30 \mathrm{~dB}$ 程度の良好な特性がそれぞれ得 られていることも確認できる。

ここで，人体に電極を接触させて通信を行う従来の 人体通信の伝送特性が $-50 \mathrm{~dB}$ であること[4]を考える と, 磁界共振結合を利用したボディエリア通信では, 従来方式に比べて 100 倍以上良好な伝送特性が実現で きることを意味している。このことから, 磁界共振結 合は, ボディエリアネットワークを形成する有力な通 信技術であると言える。

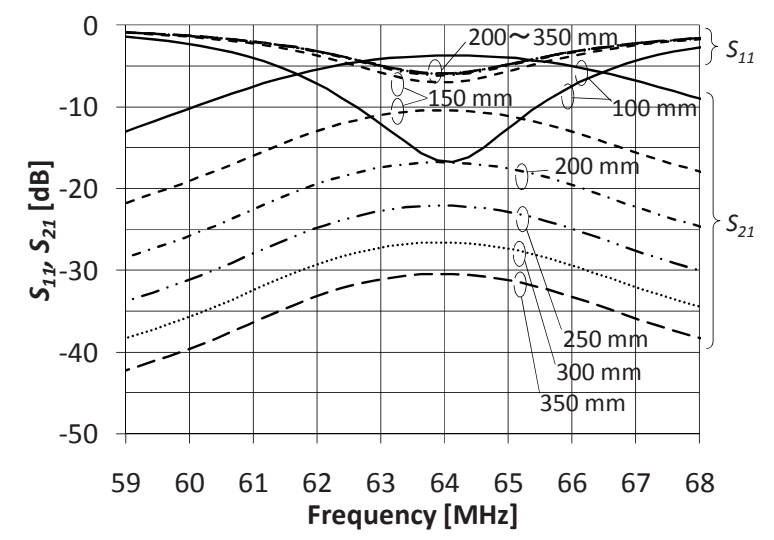

Fig. 5 Transmission characteristics $S_{21}$ for several distances between antenna coils obtained from electromagnetic field analyses.
5.2 送受信アンテナコイルの半径に対する伝送特性

次に, アンテナコイルの半径 $r$ に対する伝送特性を 検討する。Fig. 7 および Fig. 8 は，アンテナコイルの半 径 $r$ に対する伝送特性を電磁界解析および測定した結 果である。各図は，反射特性が最小，または，伝送特 性が最大となる周波数を中心にして表示している。

Figs. 7，8 からわかるとおり, アンテナコイルの半径が 大きくなると，伝送特性 $S_{21}$ が最大となるアンテナコ イルの共振周波数が低下寸ることがわかる。これは, アンテナコイルの半径の増加によって, アンテナコイ ルのインダクタンスが大きくなり，共振周波数が低下 するためである。

\section{3 送受信アンテナコイルのピッチに対する伝送特性}

ここでは，アンテナコイルのピッチ $p$ に対する伝送 特性を検討する。Fig. 9 および Fig. 10 は，アンテナコ イルのピッチ $p$ に対する伝送特性を電磁界解析および 測定した結果である。各図は，反射特性が最小，また は，伝送特性が最大となる周波数を中心にして表示し ている。Figs. 9，10からわかるとおり，アンテナコイ ルのピッチ $p$ が小さくなると, 共振周波数が低下し, 伝送特性 $S_{21}$ が最大となる周波数が低下寸ることがわ かる。これは，ピッチが小さくなることによってアン テナコイルのインダクタンスが大きくなり，共振周波 数が低下寸るためと考えられる。

\section{4 送受信アンテナコイルの巻数に対する伝送特性}

最後に, アンテナコイルの巻数 $n$ に対寸る伝送特性 を検討寸る。Fig. 11 および Fig. 12 は，アンテナコイル の巻数 $n$ に対する伝送特性を電磁界解析および測定し た結果である。各図は，反射特性が最小，または，伝

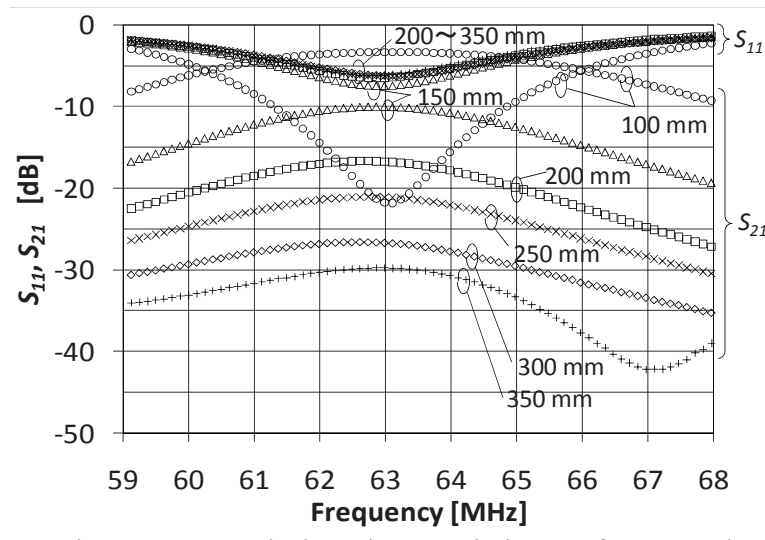

Fig. 6 Transmission characteristics $S_{2 I}$ for several distances between antenna coils obtained from measurements. 


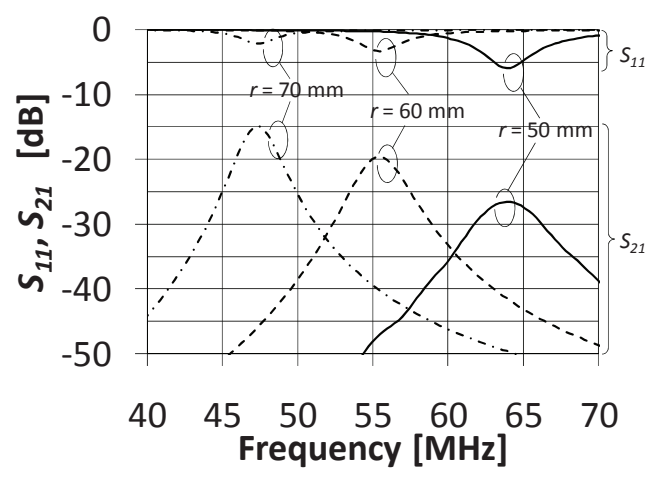

Fig. 7 Transmission characteristics $S_{21}$ for several radiuses of antenna coils obtained from electromagnetic field analyses.

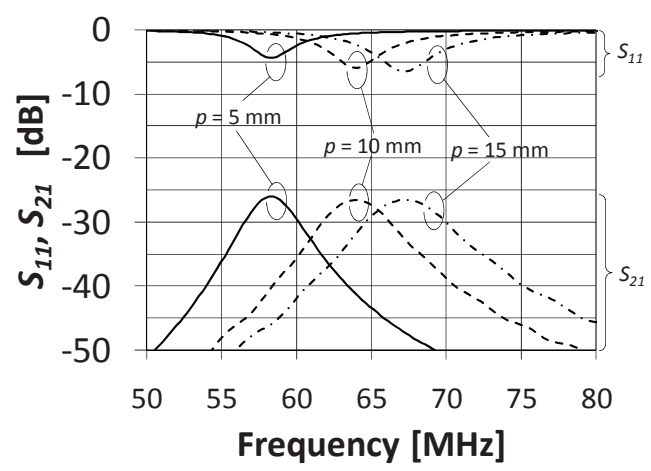

Fig. 9 Transmission characteristics $S_{2 l}$ for several pitches of antenna coils obtained from electromagnetic field analyses.

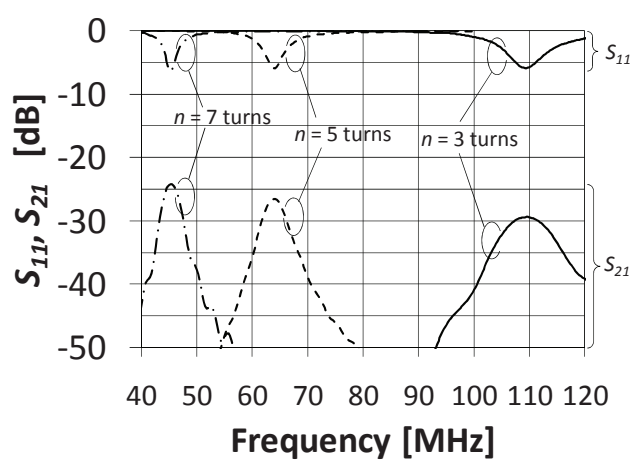

Fig. 11 Transmission characteristics $S_{21}$ for several turns of antenna coils obtained from electromagnetic field analyses.

送特性が最大となる周波数を中心にして表示している。 Fig. 11，12 からわかるとおり，アンテナコイルの巻数 が増加すると, 伝送特性 $S_{21}$ が最大となるアンテナコ イルの共振周波数が低下寸ることがわかる。これは, アンテナコイルの巻数の増加にともない, アンテナコ イルのインダクタンスが大きくなり, 共振周波数が低 下寸るためである。

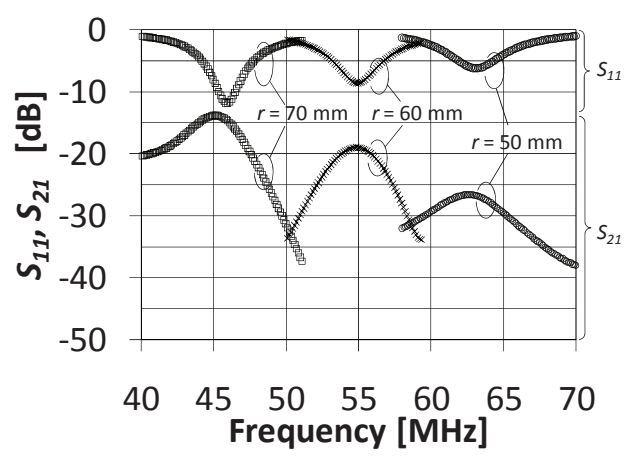

Fig. 8 Transmission characteristics $S_{2 l}$ for several radiuses of antenna coils obtained from measurements.

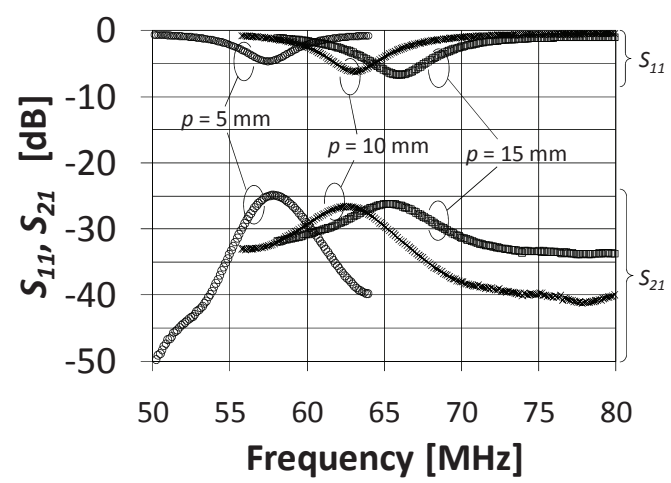

Fig. 10 Transmission characteristics $S_{21}$ for several pitches of antenna coils obtained from measurements.

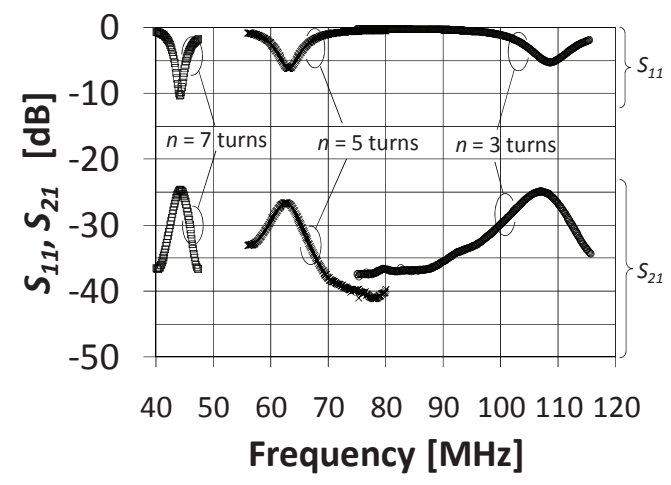

Fig. 12 Transmission characteristics $S_{21}$ for several turns of antenna coils obtained from measurements.

\section{6 電磁界分布}

Fig. 13 は，送受信コイル間の伝送距離 $D=325 \mathrm{~mm}$ としたときに, 伝送特性 $S_{21}$ が最大となる $64 \mathrm{MHz}$ にお ける電磁界分布を示している。同図(a)電界分布， (b) 磁界分布は, 解析領域における電界強度および磁界強 度の最大值をそれぞれ $0 \mathrm{~dB}$ として規格化して表示し たものである。 
Fig. 13 からわかるとおり，同図(a)の電界分布は，腕 部の影響を受けて腕部内部には電界がほとんど入り込 まず，受信アンテナコイルへの電界の結合が小さいこ とがわかる。一方, 同図(b)の磁界分布は腕部の影響を ほとんど受けずに受信アンテナコイルに効果的に磁界 が結合している様子が確認できる。また, Fig. 13(a), (b)を比較すると, 電界に比べて磁界が強い分布を示し ており，磁界が主として伝送に寄与していることがわ かる。

ここで，本稿で提案・検討した電磁界共振結合を利 用した通信が，従来の人体に電極を接触させて通信を 行う人体通信に比べて良好な伝送特性が得られるのは， 従来の人体通信が電界を励振する電極アンテナを利用 する構成であるのに対して, 本稿で提案・検討した方 式では磁界を励振するコイル型のアンテナを利用する 構成であり, そのため磁界が主として励振され, 生体 の影響を受けにくいためであると考える。

\section{7 生体安全性の検討}

磁界共振結合を利用したボディエリア通信は，新し い通信方式であるため, 生体への安全性についても検 討する必要がある。ここでは，生体安全性について，

局所 Specific Absorption Rate (SAR)值によって評価する。

日本では，局所 SAR の制限值として，任意の $10 \mathrm{~g}$ 当たりの生体組織に 6 分間に吸収されるエネルギー量 の平均值が $2.0 \mathrm{~W} / \mathrm{kg}$ 以下とするように定められている [11]。

Fig. 14 は, 送信アンテナコイルの出力電力を $1 \mathrm{~mW}$ として, 局所 SAR の制限值である $2 \mathrm{~W} / \mathrm{kg}$ を基準 $(0 \mathrm{~dB})$ として表示したものである。ここで, アンテナの出力 電力 $1 \mathrm{~mW}$ は, Bluetooth の標準的なデバイスが出力す る電力と等しいものであり[12]，ここではこれをアン テナコイルの送信出力とした。

Fig. 14 からわかるとおり, 送信コイル装着部分であ っても，SAR 值は-25 dB 以下，すなおち，制限值であ る $2 \mathrm{~W} / \mathrm{kg}$ の 1/300 以下であり, 生体安全性は十分に高 いことが確認された。

\section{8 まとめ}

本稿では，良好な伝送特性を実現する新しいボディ エリア通信技術として，磁界共振結合を利用したボデ イエリア通信を提案し, 人体腕部にアンテナコイルを 装着したときのアンテナコイル間の伝送特性, および, 電磁界分布を検討し, 最後に, 磁界共振結合によるボ

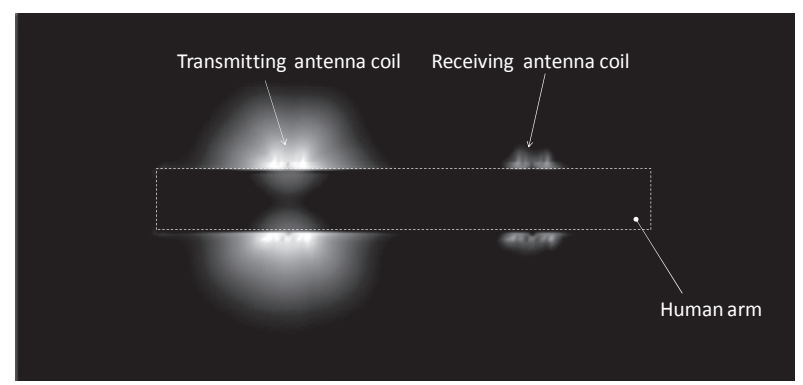

(a) Electric field distribution

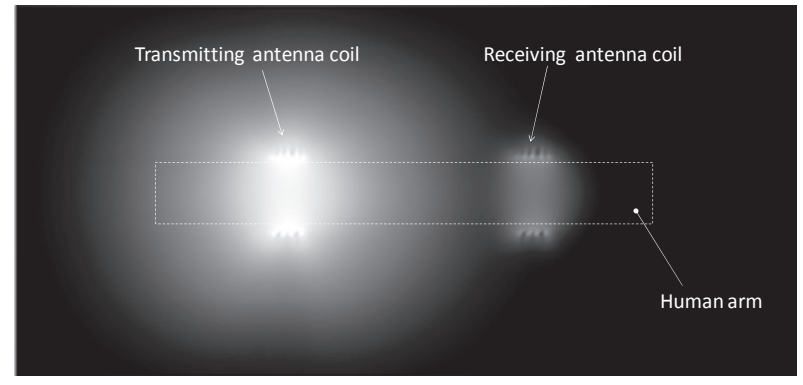

(b) Magnetic field distribution

Normalized electric field / Normalized magnetic field [dB]

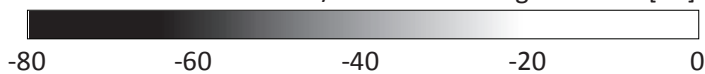

Fig. 13 Electromagnetic field distributions.

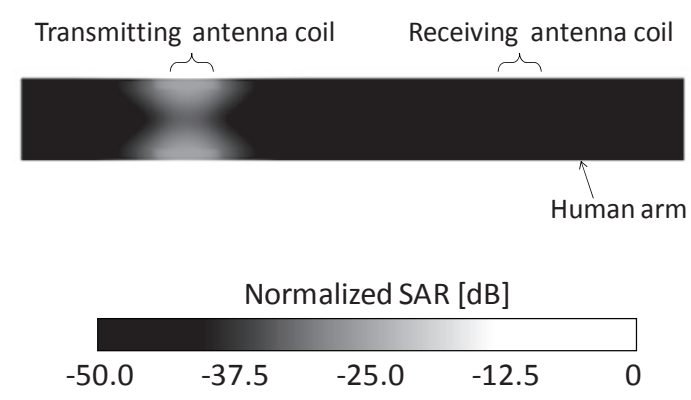

Fig. 14 SAR distribution.

ディエリア通信の生体安全性について SAR によって 評価を行った。

その結果，腕部に装着した送受信アンテナコイル間 の伝送特性 $S_{21}$ は, 伝送距離 $D=100 \mathrm{~mm}$ において, $S_{2 I}=$ $-3 \mathrm{~dB}, D=350 \mathrm{~mm}$ において, $S_{21}=-31 \mathrm{~dB}$ の良好な特 性がそれぞれ得られ，従来の人体に電極を接触させて 通信を行う人体通信 $\left(S_{21}=-50 \mathrm{~dB}\right)$ に比べて, 100 倍以上 良好な伝送特性が実現できること確認した。

また，腕部に装着されたアンテナコイルがつくる電 磁界分布に着目すると, 電界は生体の影響を受け，腕 部内部には入り込まずアンテナコイル周囲にのみ分布 
するが，磁界は生体の影響を受けにくく，送受信コイ ル間が磁気的に良く結合している様子が確認された。 これにより磁界を積極的に利用することで，従来の人 体に電極を接触させて通信を行う人体通信に比べて良 好な特性が得られることがわかった。

また，送信アンテナコイルの出力電力を $1 \mathrm{~mW}$ とし た時の, 局所 SAR 值は, 制限值 $2 \mathrm{~W} / \mathrm{kg}$ の 1/300 以下 であり, 生体への安全性も十分確保されていることを 示した。

以上から，磁界共振結合がボディエリアネットワー クを形成する通信技術として有望であることを確認し た。

(2012 年 10 月 1 日受付, 2013 年 2 月 7 日再受付)

\section{参考文献}

[1] 尾崎徹, 小見正幸, 杉本千佳, 柴建次, 苗村潔, 保坂寛, 板生清, 佐々木健, ヘルスケア用ウェアラブルセンシン グユニットの開発研究, マイクロメカトロニクス, Vol. 47, No. 3, pp. 12-19, 2003.

[2] Huan-Bang Li, Kenichi Takizawa, Ryuji Kohno, Trends and Standardization of Body Area Network (BAN) for Medical Healthcare, European Conference on Wireless Technology (EuWiT 2008), pp. 1-4, 2008.

[3] Ken SASAKI, Fukuro KOSHIJ, Shudo TAKENAKA, Intrabody Communication Using Contact Electrodes in Low-Frequency Bands, CRC Press, Taylor and Francis, Healthcare Sensor Networks - Challenges toward Practical Application, ISBN-13: 978-1439821817, Chaper 3, pp. 51-73, 2011.

[4] 越地福朗, 佐々木健, 人体内通信におけるウェアラブル 送信機の電極構造によるインピーダンス整合と電極設計, エレクトロニクス実装学会誌, Vol. 12, No. 3, pp. 221-232, 2009.

[5] 湯山菜奈子, 越地福朗, 越地耕二, 電磁界共振結合を利用 した人体周辺通信における伝送特性の検討, 第 22 回マイク ロエレクトロニクスシンポジウム論文集, 2C4-4, pp. 241-244, 2012.

[6] S. Gabriel, et al., The dielectric properties of biological tissues: II. Measurements in the frequency range $10 \mathrm{~Hz}$ to $20 \mathrm{GHz}$, Phys. Med. Biol. 41, pp. 2251-2269, 1996.

[7] International Federation of Automatic Control (IFAC) website (http://niremf.ifac.cnr.it/tissprop/).

[8] 生命工学工業技術研究所, 設計のための人体寸法データ 集, 人間生活工学研究センター, 日本出版サービス, ISBN-10: 987-4889220933, 1996.

[9] 総務省, 携帯電話端末の電波が植込み型心臓ペースメー 力等へ及ぼす影響の検討, 総務省電波の医用機器等への 影響に関する調查研究報告書, pp. 1-34, 2005.

[10] 総務省, RFID 機器の電波が植込み型心臟ペースメーカ 等へ及ぼす影響の検討, 総務省電波の医用機器等への影 響に関する調查研究報告書, pp. 35-69, 2005.

[11] 総務省 電波防護指針 (http://www.tele.soumu.go.jp/j/sys/ele/index.htm).

[12] 宮津和弘, Bluetooth のしくみとハードウェア構成, Design Wave Magazine, No. 29, pp. 65-73, 2000. 